\title{
PELATIHAN PENGGUNAAN APLIKASI QUIZIZZ DAN WORDWALL PADA PEMBELAJARAN IPA BAGI GURU-GURU SDIT AL-KAHFI
}

\author{
Prima Mutia Sari'1), Husnin Nahry Yarza' ${ }^{2)}$ \\ 1)Program Studi Pendidikan Guru Sekolah Dasar, FKIP, Universitas Muhammadiyah Prof. DR. HAMKA, Jakarta, DKI \\ Jakarta, Indonesia \\ 2)Program Studi Pendidikan Biologi, FKIP, Universitas Muhammadiyah Prof. DR. HAMKA, Jakarta, DKI Jakarta, \\ Indonesia \\ Corresponding author : Prima Mutia Sari \\ E-mail : primamutiasari@uhamka.ac.id
}

Diterima 15 Februari 2021, Direvisi 02 Maret 2021, Disetujui 08 Maret 2021

\begin{abstract}
ABSTRAK
Pandemi Covid-19 telah merubah proses pembelajaran di sekolah dasar dari pembelajaran luring menjadi pembelajaran daring. Salah satu kendala yang dihadapi guru sekolah dasar adalah penggunaan aplikasi pembelajaran daring yang menarik bagi siswa. Kegiatan pengabdian ini merupakan pelatihan penggunaan aplikasi Quizziz dan Wordwall dalam pembelajaran bagi guru-guru SDIT Al-Kahfi. Sasaran dari kegiatan ini adalah 25 orang guru yang merupakan mitra pengabdian. Kegiatan dilaksanakan secara daring melalui platform Zoom . Kegiatan terdiri dari dua tahap yaitu 1) Pemaparan materi dan praktek penggunaan aplikasi Quizizz, 2) Pemaparan materi dan praktek penggunaan aplikasi Wordwall. Teknik pengumpulan data menggunakan angket atau kuesioner. Analisis data menggunakan rata-rata respon peserta. Hasil respon peserta menunjukkan hasil yang positif dimana para guru mendapatkan pengetahuan dan keterampila dalam penggunaan aplikasi Quizizz dan Wordwall. Kendala dalam kegiatan ini terkait dengan kestabilan jaringan internet.
\end{abstract}

Kata kunci: quizizz; wordwall; sekolah dasar

\begin{abstract}
Pandemic Covid-19 has changed the learning process in the elementary school from offline learning to online learning. One of the obstacles faced by elementary school teachers was the use of online learning application that were attractive for students. This service activity was a training on the use of the Quizziz and Wordwall applications in learning for SDIT Al-Kahfi teachers. The target of this activity is 25 teachers. The activity consists of two stages, namely 1) Presentation of the material and practice of using the Quizizz application, 2) Presentation of the material and practice of using the Wordwall application. Data collection techniques was a questionnaire. Data analysis using the average of participant responses. The results of the participants' responses showed positive results where the teachers gained knowledge and skills in using the Quizizz and Wordwall applications. The obstacles in this activity are related to the stability of the internet network.
\end{abstract}

Keywords: quizizz; wordwall; elementary school

\section{PENDAHULUAN}

Pandemi Covid-19 yang melanda berbagai dunia pada saat sekarang ini telah mengubah paradigma dalam dunia Pendidikan. Pembelajaran yang biasanya dilakukan secara offline atau luar jaringan sekarang berubah menjadi pembelajaran online atau dalam jaringan. Hal ini merupakan tantangan tersendiri yang dihadapi oleh seluruh unsur pendidikan seperti guru dan siswa. Banyak guru yang belum siap dalam menghadapi perubahan proses pembelajaran termasuk dalam pembelajaran IPA. Pembelajaran IPA seharusnya tidak hanya menekankan pada produk akhir, akan tetapi juga berorientasi pada proses melalui aktivitas pembelajaran di kelas.
Kemudian dalam pembelajaran IPA juga terdapat materi yang membutuhkan visualisasi yang menarik bagi siswa terutama dalam pembelajaran daring. Salah satu cara untuk mengatasi hal ini adalah dengan menggunakan aplikasi pembelajaran berbentuk kuis online dengan gambar dan musik yang banyak dikembangkan pada saat sekarang ini. Hal ini terbukti dengan kegiatan yang dilaksanakan di salah satu sekolah dasar di Jakarta, dimana guru-guru menyampaikan bahwa mereka membutuhkan banyak pengetahuan tentang berbagai aplikasi untuk pembelajaran daring (Sari \& Zulfadewina, 2020).

Seiring perkembangan teknologi di era Revolusi Industri 4.0, ada banyak aplikasi yang 
dapat digunakan oleh guru dalam pembelajaran daring contohnya aplikasi Quizizz dan Wordwall. Quizizz merupakan sebuah web tool untuk membuat permainan kuis interaktif untuk digunakan dalam pembelajaran di kelas. Aplikasi ini sifatnya online artinya dapat digunakan jika ada dukungan internet yang memadai. Quizizz mudah dibuat dan dimainkan sebagai media pembelajaran. Sebelum masuk ke www.Quizizz.com guru harus menyiapkan materi dalam bentuk pertanyaan dan alternatif jawaban yang nanti ditampilkan dalam aplikasi ini (Aini, 2019). Aplikasi Quizizz memiliki tampilan yang sangat menarik, serta mempunyai latar belakang musik dengan pilihan dinyalakan atau dimatikan. Jika siswa senang belajar dengan musik maka mereka dapat menyalakan music tersebut, sedangkan jika siswa membutuhkan belajar yang tenang dan sunyi maka musik dapat dimatikan. Di dalam aplikasi Quizizz juga terdapat gambargambar menarik yang akan muncul ketika siswa menjawab benar atau salah (Kinanti \& FX.Mas Subagio, 2020). Penggunaan aplikasi Quizziz dapat menarik perhatian siswa dan membuat siswa lebih fokus dalam pembelajaran (Mei et al., 2018).

Wordwall adalah sebuah aplikasi yang dapat dijadikan sebagai media pembelajaran, sumber belajar atau alat penilaian berbasis daring yang menarik bagi siswa. Kelebihan dari aplikasi ini adalah mempunyai banyak template yang dapat dibuat oleh guru. Aplikasi ini tidak berbayar untuk pilihan Basic dengan pilihan 5 buah template. Permainan yang sudah dibuat dapat langsung dibagikan melalui tautan yang dikirimkan dengan aplikasi Whatsapp, Google Classroom maupun Email. Selain itu, kelebihan lainnya dari aplikasi ini adalah permainan yang sudah dirancang dapat dicetak dalam bentuk PDF sehingga memudahkan siswa yang terkendala jaringan. Banyak jenis permainan yang ditawarkan oleh software evaluasi pembelajaran ini, termasuk permainan klasik seperti Quiz (kuis) dan Crossword (teka-teki silang). Ada juga tipe permainan seperti; Find the Match (Mencari padanan), Random Wheel (Roda acak), Missing Word, Random cards (Kartu acak), True or False (Benar atau salah), Match up, Whack-a-mole, Group short, Hangman, Anagram, Open the Box, Wordsearch (Cari kata), Ballon pop, Unjumble, Labelled diagram, dan Gameshow Quiz (Sun'iyah, 2020).

Selanjutnya, menurut hasil wawancara dengan beberapa orang guru di SDIT AI Kahfi diketahui bahwa sebagian besar guru masih mengalami kesulitan dalam menerapkan pembelajaran daring. Pembelajaran dilakukan melalui video pembelajaran yang dibuat oleh guru lalu diunggah ke Youtube dan dibagikan kepada siswa melaui aplikasi Whatsapp. Selain itu ada juga guru-guru yang menggunakan Zoom Meeting dan Google Classroom. Hal ini sesuai dengan hasil penelitian Handarini \& Siti Sri Wulandari, (2020) yang mengemukakan bahwa beberapa aplikasi seperti Whatsapp, Video Conference, Google Form digunakan sebagai media untuk pemberian tugas dalam pembelajaran daring selama ini. Pembelajaran seperti cenderung monoton karena kegiatan yang dilakukan kurang menarik khususnya dalam pembelajaran IPA. Selanjutnya, SDIT AIKahfi mempunyai jumlah guru yang cukup banyak dan diharapkan dapat meningkatkan wawasan dalam penguasaan teknologi pembelajaran.

Berdasarkan permasalahan di atas maka dipandang perlu untuk meningkatkan pemahaman, dan keterampilan guru SD dalam menggunakan aplikasi Quizizz dan Wordwall untuk meningkatkan kualitas pembelajaran daring.

\section{METODE}

Kegiatan pengabdian masyarakat dilaksanakan pada hari Jumat, 22 Januari 2021. Kegiatan dilakukan secara daring melalui platform Zoom dan diikuti oleh 25 orang guru SDIT Al-Kahfi. Kegiatan pengabdian dilakukan dalam bentuk pelatihan yang terdiri dari tiga tahapan yaitu :

A. Tahap Persiapan

Tahap persiapan meliputi pengurusan izin dan surat menyurat dengan sekolah mitra. Kemudian dilanjutkan dengan koordinasi mengenai waktu dan tempat pelaksanaan kegiatan dengan kepala sekolah. Setelah itu tim pengabdian akan menyiapkan bahan-bahan untuk pelatihan seperti modul pelatihan.

\section{B.Tahap Pelaksanaan}

Pengabdian kepada masyarakat yang akan dilaksanakan, terdiri dari beberapa tahapan kegiatan yaitu sebagai berikut :

1. Paparan materi tentang penggunaan aplikasi Quizizz

2. Praktek penggunaan aplikasi Quizizz

3. Paparan materi tentang penggunaan aplikasi Wordwall

4. Praktek penggunaan aplikasi Wordwall

C.Tahap Evaluasi

Pada tahap ini dilakukan evaluasi terhadap kegiatan pelatihan yang telah dilaksanakan dengan cara memberikan angket kepada peserta pelatihan melalui aplikasi Googleform. 


\section{HASIL DAN PEMBAHASAN}

Kegiatan pelatihan terdiri dari dua sesi. Pertama, sesi tentang penggunaan aplikasi Quizzizz. Narasumber menjelaskan aplikasi Quiziziz berguna sebagai salah satu alat evaluasi dalam pembelajaran daring. Aplikasi ini dapat digunakan di laptop dengan cara membuka web https://Quizizz.com atau di gadget peserta didik dengan cara mendownload aplikasi Quizizz di playstore. Hal ini menjadi salah satu kelebihan Quizziz dibanding aplikasi lainnya karena siswa dapat langsung melihat soal dan jawaban di Handphone atau gadget masing-masing (Suharsono, 2020). Setelah pemaparan materi, peserta diminta mempraktekkan langsung membuat soal dengan aplikasi Quizizz. Kegiatan berlangsung seperti pada Gambar 1.

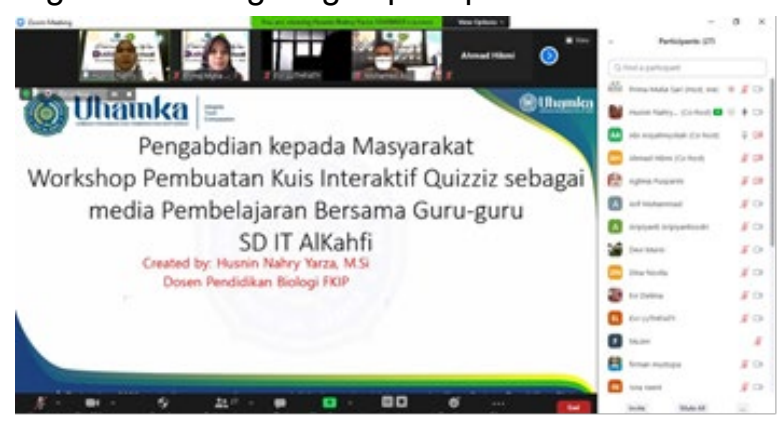

Gambar 1. Pemaparan Materi Penggunaan Aplikasi Quizziz

Penggunaan aplikasi Quizizz dalam pembelajaran daring dapat membuat siswa menjadi lebih tertarik dan memotivasi kerja otak siswa (Salsabila et al., 2020).

Kedua, sesi tentang penggunaan aplikasi Wordwall. Pada awalnya narasumber meminta peserta untuk mengklik tautan yang ada di room chat kemudian peserta diminta mengerjakan kuis di tautan tersebut. Semua peserta mengaku belum pernah melihat permainan atau kuis tersebut. Selanjutnya, narasumber menjelaskan penggunaan aplikasi Wordwall dan di akhir pemaparan peserta diminta mempraktekkan langsung cara membuat soal atau permainan menggunakan aplikasi Wordwall. Pemaparan materi oleh narasumber dapat dilihat pada Gambar 2.

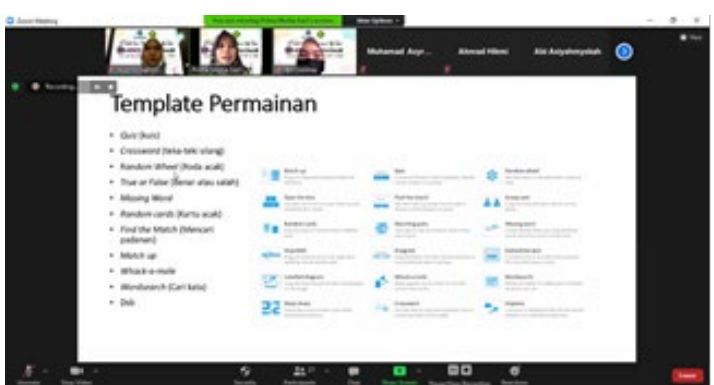

Gambar 2. Pemaparan Materi Penggunaan Aplikasi Wordwall

Pelatihan ini memberikan dampak yang cukup baik bagi mitra, berdasarkan hasil wawancara sebelum kegiatan dilaksanakan diketahui bahwa untuk aplikasi Quizizz baru digunakan oleh guru kelas rendah, sedangkan untuk aplikasi Wordwall belum pernah digunakan oleh guru-guru. Setelah diadakan pelatihan, semua guru sudah mengetahui dan mampu menggunakan kedua aplikasi tersebut. Perbandingan kemampuan guru sebelum dan sesudah pelatihan dapat dilihat pada table $1 \mathrm{di}$ bawah ini.

Tabel 1. Perbandingan Jumlah Guru yang Menguasai Aplikasi Quizizz dan Wordwall

\begin{tabular}{cccc}
\hline $\begin{array}{c}\text { Penggunaan } \\
\text { Aplikasi Quizizz }\end{array}$ & \multicolumn{2}{c}{$\begin{array}{c}\text { Penggunaan } \\
\text { Aplikasi Wordwall }\end{array}$} \\
\hline Sebelum & Sesudah & Sebelum & Sesudah \\
\hline 11 & 25 & 0 & 25 \\
\hline
\end{tabular}

Selanjutnya, dilakukan evaluasi kegiatan pengabdian masyarakat dalam bentuk pelatihan penggunaan aplikasi Quizziz dan Wordwall menggunakan angket dalam bentuk google form yang diberikan kepada peserta di akhir kegiatan. Rekapitulasi hasil angket dapat dilihat dalam Gambar 3 di bawah ini:

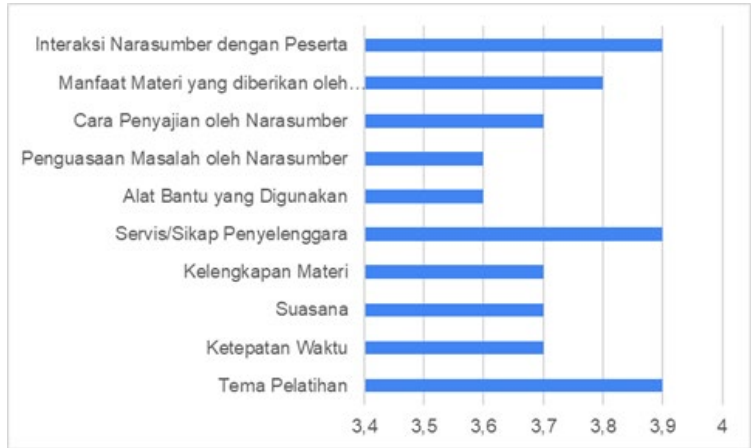

Gambar 3. Rekapitulasi Hasil Angket Peserta

Selanjutnya kategori hasil angket peserta dapat dilihat pada Tabel 2 di bawah ini. 
Tabel 1. Kategori Hasil Angket Peserta

\begin{tabular}{lll}
\hline \multicolumn{1}{c}{ Pelaksana Pelatihan } & $\begin{array}{c}\text { Rata-Rata } \\
\text { Nilai }\end{array}$ & Kategori \\
\hline Tema Pelatihan & 3,9 & Bagus \\
\hline Ketepatan Waktu & 3,7 & Bagus \\
\hline Suasana & 3,7 & Bagus \\
\hline $\begin{array}{l}\text { Kelengkapan Materi } \\
\text { Servis/Sikap }\end{array}$ & 3,7 & Bagus \\
$\begin{array}{l}\text { Penyelenggara } \\
\text { Alat Bantu yang } \\
\text { Digunakan }\end{array}$ & 3,9 & Bagus \\
\hline $\begin{array}{l}\text { Penguasaan Masalah } \\
\text { oleh Narasumber }\end{array}$ & 3,6 & Bagus \\
$\begin{array}{l}\text { Cara Penyajian oleh } \\
\text { Narasumber }\end{array}$ & 3,6 & Bagus \\
\hline $\begin{array}{l}\text { Manfaat Materi yang } \\
\text { diberikan oleh }\end{array}$ & & Bagus \\
$\begin{array}{l}\text { Narasumber } \\
\begin{array}{l}\text { Interaksi Narasumber } \\
\text { dengan Peserta }\end{array}\end{array}$ & 3,8 & Bagus \\
\hline
\end{tabular}

Berdasarkan hasil angket yang terkumpul didapat keterangan bahwa tema pelatihan, ketepatan waktu, suasana, kelengkapan materi, servis atau sikap penyelenggara serta penggunaan alat bantu yang digunakan dalam kegiatan pelatihan ini sudah bagus. Kemudian dari sisi narasumber dan materi yang disajikan juga mendapat respon positif dari peserta. Menurut peserta, penguasaan masalah, cara penyajian, manfaat materi serta interaksi narasumber dengan peserta sudah bagus. Selain itu, peserta sangat antusias dan tertarik karena diberi kesempatan untuk bertanya dan ikut serta dalam mempraktikkan materi yang sudah dijelaskan. Secara umum hasil respon peserta menunjukkan hasil yang positif dimana para guru mendapatkan pengetahuan dan keterampilan dalam penggunaan aplikasi Quizizz dan Wordwall. Hal ini sangat penting karena guru masa kini harus mampu menciptakan pembelajaran yang memafsilitasi kebutuhan Genereasi $Z$ yang lahir pada tahun 2000 an dan dekat dengan segala sesuatu yang berbasis daring (Situmorang \& Christie Lidya Rumerung, Dwi Yulianto Nugroho, Peggy Sara T., 2019) .

Selanjutnya dari komentar yang dituliskan peserta dalam angket diperoleh bahwa $90 \%$ peserta merasa senang dengan pelatihan penggunaan aplikasi Quizizz dan Wordwall dalam pembelajaran karena menambah ilmu dan dirasa sangat bermanfaat dalam kegiatan pembelajaran khususnya dalam pembelajaran daring. Akan tetapi terdapat beberapa kendala dalam pelatihan ini seperti kendala jaringan atau internet yang kurang stabil dari salah satu narasumber saat pemaparan materi. Hal ini memang menjadi kendala utama dalam pembelajaran daring seperti diungkapkan dalam salah satu penelitian bahwa beberapa kendala dalam pembelajara daring adalah kualitas sinyal dan sulitnya mencari jaringan internet (Anugrahana, 2020). Selanjutnya, berdasarkan saran-saran dari peserta sebaiknya lebih sering diadakan kegiatan pelatihan seperti ini agar para guru dapat mengembangkan ilmu yang mereka miliki. Peserta juga mengharapkan adanya kegiatan sejenis seperti pelatihan pembuatan video pembelajaran, media pembelajaran daring dan sebagainya. Saran dan perbaikan dari peserta dapat dijadikan sebagai bahan evaluasi bagi pelaksana untuk kegiatan pengabdian berikutnya.

\section{SIMPULAN DAN SARAN}

Adapun kesimpulan dari kegiatan pelatihan ini adalah sebagai berikut : 1) Kegiatan pelatihan dapat mengatasi permasalahan mitra yaitu dapat meningkatkan pengetahuan dan keterampilan guru dalam penggunaan aplikasi Quizziz dan Wordwall, 2) Kendala yang dihadapi adalah adanya gangguan jaringan saat pemaparan materi. Saran untuk kegiatan berikutnya adalah memastikan kestabilan jaringan internet serta mengadakan kegiatan pelatihan sejenis untuk peningkatan kualitas guru dalam pembelajaran daring.

\section{UCAPAN TERIMAKASIH}

Terima kasih kepada Lembaga Pengabdian dan Pemberdayaan Masyarakat (LPPM) Universitas Muhammadiyah Prof. DR. HAMKA yang sudah mendanai kegiatan pelatihan ini.

\section{DAFTAR RUJUKAN}

Aini, Y. I. (2019). Pemanfaatan Media Pembelajaran Quizizz Untuk Pembelajaran Jenjang Pendidikan Dasar Dan Menengah Di Bengkulu. Jurnal Kependidikan, 2(25), 1-6.

Anugrahana, A. (2020). Hambatan, Solusi dan Harapan: Pembelajaran Daring Selama Masa Pandemi Covid-19 Oleh Guru Sekolah Dasar. Scholaria: Jurnal Pendidikan Dan Kebudayaan, 10(3), 282-289.

https://doi.org/10.24246/j.js.2020.v10.i 3.p282-289

Handarini, O. I., \& Siti Sri Wulandari. (2020). Pembelajaran Daring Sebagai Upaya Study From Home (SFH) Selama Pandemi Covid 19. Jurnal Pendidikan Administrasi Perkantoran (JPAP), 8(3), 496-503.

https://doi.org/10.1093/fampra/cmy005 
Kinanti, M. D., \& FX.Mas Subagio. (2020). PENGEMBANGAN LKPD BAHASA INGGRIS BERBANTU APLIKASI QUIZIZZ KELAS IV SEKOLAH DASAR. JPGSD, 8(3), 1-10.

Mei, S. Y., Ju, S. Y., \& Adam, Z. (2018). Implementing Quizizz as Game Based Learning in the Arabic Classroom. European Journal of Social Sciences Education and Research, 12(1), 208. https://doi.org/10.26417/ejser.v12i1.p2 08-212

Salsabila, U. H., Habiba, I. S., Amanah, I. L., Istiqomah, N. A., \& Difany, S. (2020). Pemanfaatan Aplikasi Quizizz Sebagai Media Pembelajaran Ditengah Pandemi Pada Siswa SMA. Jurnal IImiah IImu Terapan Universitas Jambi|JIITUJ|, 4(2), 163-173. https://doi.org/10.22437/jiituj.v4i2.1160 5

Sari, P. M., \& Zulfadewina. (2020). Pelatihan Penyusunan Instrumen Keterampilan Proses Sains Berbantuan Media Kahoot. DIKEMAS (Jurnal Pengabdian Kepada Masyarakat), 4(2), 93-98.

Situmorang, K., \& Christie Lidya Rumerung, Dwi Yulianto Nugroho, Peggy Sara T., M. M. Y. A. (2019). Pemanfaatan Teknologi dalam Pendidikan: Penggunaan fitur gamifikasi daring di SMA-SMK Kristen PENABUR Bandar Lampung. Prosiding Konferensi Nasional Pengabdian Kepada Masyarakat Dan Corporate Social Responsibility (PKM-CSR), 2, 869-877. https://doi.org/10.37695/pkmcsr.v2i0.3 94

Suharsono, A. (2020). The Use of Quizizz and Kahoot! In The Training for Millennial Generation. Journal, International Education, Indonesian, 4(2), 332-342.

Sun'iyah, S. L. (2020). Media Pembelajaran Daring Berorientasi Evaluasi Pada Mata Pelajaran PAI di Tingkat Pendidikan Dasar. DAR EL-ILMI: Jurnal Studi Keagamaan, Pendidikan Dan Humaniora, 7(1), 1-18. 